\title{
Bone morphogenetic proteins in tissue engineering: the road from the laboratory to the clinic, part I (basic concepts)
}

\author{
P. C. Bessa ${ }^{1,2,3 *}$, M. Casal ${ }^{3}$ and R. L. Reis ${ }^{1,2}$ \\ ${ }^{1}$ 3Bs Research Group, Biomaterials, Biodegradables and Biomimetics, Department of Polymer Engineering, University of Minho, \\ Campus de Gualtar, 4710-057 Braga, Portugal \\ ${ }^{2}$ Institute for Biotechnology and Bioengineering (IBB), PT Government Associated Laboratory, 4710-057 Braga, Portugal \\ ${ }^{3}$ Molecular and Environmental Biology Centre (CBMA)/Biology Department, University of Minho, Campus de Gualtar, 4710-057 \\ Braga, Portugal
}

\begin{abstract}
Discovered in 1965, bone morphogenetic proteins (BMPs) are a group of cytokines from the transforming growth factor- $\beta$ (TGF $\beta$ ) superfamily with significant roles in bone and cartilage formation. BMPs are used as powerful osteoinductive components of diverse tissue-engineering products for the healing of bone. Several BMPs with different physiological roles have been identified in humans. The purpose of this review is to cover the biological function of the main members of BMP family, the latest research on BMPs signalling pathways and advances in the production of recombinant BMPs for tissue engineering purposes. Copyright $\odot 2008$ John Wiley \& Sons, Ltd.
\end{abstract}

Received 26 November 2007; Accepted 2 January 2008

Keywords bone morphogenetic proteins; bone morphogenetic protein receptor; Smad signalling; BMP signalling; recombinant BMP; tissue engineering

\section{Body morphogenetic proteins}

Research on bone regeneration began decades ago as a result of intensive studies on bone growth and healing. Bone has been recognised, among the many tissues in human body, as one with the highest potential for regeneration. As early as 1889 Senn noticed that decalcified bone could induce healing of bone defects (Senn, 1889). Later Lavender provided the first evidence of ectopic bone formation after injecting bone crude extracts into muscle (Levander, 1934, 1938). In 1965 the pioneering work by Urist marked a landmark on the research in bone regeneration. Urist discovered that the active compound responsible for bone regeneration was a mix of proteins and named these as bone morphogenetic proteins (BMPs; Urist, 1965). In the years that followed Sampath and Reddi created a crude but highly reproducible bioassay for BMP for ectopic bone

*Correspondence to: P. C. Bessa, 3Bs Research Group, Biomaterials, Biodegradables and Biomimetics, Department of Polymer Engineering, University of Minho, Campus de Gualtar, 4710057 Braga, Portugal. E-mail: paulo.bessa@dep.uminho.pt formation (Sampath and Reddi, 1981). The assay was based on the activity of the enzyme alkaline phosphatase enzyme and the content of calcium in the newly formed bone. Reddi proposed that BMPs are responsible for the initiation of a cascade of developmental events, in which progenitor cells in the bone marrow were induced by these factors to produce bone cells leading to bone regeneration (Reddi and Huggins, 1972; Reddi, 1981).

During the decades of 80 s and 90s the BMP genes were cloned and the recombinant proteins were shown to be biologically potent (Wozney et al., 1988). Much work followed with the use of recombinant BMPs (rhBMPs) for clinical applications such as spinal fusion, fracture healing and dental tissue engineering (Nakashima and Reddi, 2003; Seeherman and Wozney, 2005). Human BMPs are now produced in larger amounts by recombinant technology. In 2002 FDA gave approval of two products containing rhBMP-2 and rhBMP-7 in absorbable collagen carriers for spinal fusion and long bone non-unions (McKay et al., 2007; White et al., 2007). In a recent review Reddi proposed naming BMPs also as body morphogenetic proteins, due to their extensive roles in various tissues and organs beyond the bone (Reddi, 2005). 


\section{Members of the BMP family}

In humans several members are under the designation of BMPs, from BMP-2 to BMP-18 (Table 1). BMP-1 is not a member of the BMP family. It is a misidentified protein with chordinase and procollagen proteinase activities, implicated in embryonic patterning (Kessler et al., 1996). In fact, since BMPs were named by homology-based cDNA cloning, there is confusion over BMP designations and there is a need to develop a more appropriate nomenclature for the BMP family.

The biological functions of BMPs are mainly related to bone and cartilage formation (Reddi, 2005), although BMP-8b, -10 and -15 do not have known roles in bone or cartilage. BMP-10 is involved in cardiac development and BMP-15 in ovarian physiology (Chen et al., 2004; Knight and Glister, 2006). BMP-8b is involved in reproductive cells (Zhao et al., 1996). Usually only BMP-2 to BMP11 are considered to be BMPs. BMP-12, -13 and 14 are named cartilage-derived morphogenetic proteins (CDMPs), as these induce chondrogenic phenotypes rather than osteogenesis (Reddi, 2003). BMPs are also involved in embryonic patterning (Kishigami and Mishina,
2005), in skeletal formation (Tsumaki and Yoshikawa, 2005) and in organogenesis of other tissues behind bone. For example, BMP-2 plays a role in heart morphogenesis (Callis et al., 2005) and in neural stem cells (White et al., 2001), BMP-7 in kidney formation (Simic and Vukicevic, 2005) and diverse BMPs have unique roles in reproductive organs (Shimasaki et al., 2004; Tsumaki and Yoshikawa, 2005). During the events of early embryogenesis, BMPs are involved in the dorsal-ventral patterning with different roles, e.g. BMP-2 and -4 induce embryo ventral differentiation, while BMP-3 and -3b oppose the ventralizing effect by inducing tail and head formation, respectively (Hino et al., 2004). During gastrulation a BMP gradient in signalling established by BMP antagonists is responsible for directing cells into forming organs such as bone, cartilage, kidney or heart, depending on the levels of BMP activity and of other cytokines (Yamamoto and Oelgeschlager, 2004). The pleiotropic effect of the different BMPs is of important consideration for tissue engineering. For instance, besides being used for differentiation of cartilage and bone BMP-4 is being studied for a role in keeping the undifferentiated state in embryonic stem cells (Qi et al., 2004). BMPs

Table 1. BMP members in humans and their main physiological roles

\begin{tabular}{|c|c|c|c|}
\hline BMP & Nomenclature & Main physiological roles & References \\
\hline \multicolumn{4}{|c|}{ Bone morphogenetic proteins } \\
\hline BMP-2 & BMP-2a & $\begin{array}{l}\text { Cartilage and bone } \\
\text { morphogenesis/heart formation }\end{array}$ & $\begin{array}{l}\text { Wang et al., 1990a; Kang et al., } \\
\text { 2004; Callis et al., } 2005\end{array}$ \\
\hline BMP-3 & Osteogenin & $\begin{array}{l}\text { Negative regulator of bone } \\
\text { morphogenesis }\end{array}$ & Hino et al., 2004 \\
\hline BMP-3b & GDF-10 & $\begin{array}{l}\text { Negative regulator of bone } \\
\text { morphogenesis }\end{array}$ & Hino et al., 2004 \\
\hline$\underline{B M P-4}$ & BMP-2b & $\begin{array}{l}\text { Cartilage and bone } \\
\text { morphogenesis/kidney formation }\end{array}$ & $\begin{array}{l}\text { Luyten et al., 1994; Kubler et al., } \\
\text { 1998a; Oxburgh et al., } 2005\end{array}$ \\
\hline BMP-5 & - & $\begin{array}{l}\text { Limb development/bone } \\
\text { morphogenesis }\end{array}$ & $\begin{array}{l}\text { Cho et al., 2002; Zuzarte-Luis et al., } \\
2004\end{array}$ \\
\hline$\underline{B M P-6}$ & Vrg1, Dvr6 & $\begin{array}{l}\text { Hypertrophy of cartilage/bone } \\
\text { morphogenesis/oestrogen mediation }\end{array}$ & $\begin{array}{l}\text { Gitelman et al., 1994; Rickard et al., } \\
\text { 1998; Kang et al., } 2004\end{array}$ \\
\hline$\underline{B M P-7}$ & OP-1 & $\begin{array}{l}\text { Cartilage and bone } \\
\text { morphogenesis/kidney formation }\end{array}$ & $\begin{array}{l}\text { Reddi, 1998; Kang et al., 2004; Simic } \\
\text { and Vukicevic, } 2005\end{array}$ \\
\hline BMP-8 & OP-2 & $\begin{array}{l}\text { Bone } \\
\text { morphogenesis/spermatogenesis }\end{array}$ & $\begin{array}{l}\text { Ozkaynak et al., 1992; Zhao et al., } \\
\text { 1996; Cho et al., } 2002\end{array}$ \\
\hline BMP-9 & GDF-2 & $\begin{array}{l}\text { Bone morphogenesis/development } \\
\text { of cholinergic neurons/glucose } \\
\text { metabolism }\end{array}$ & $\begin{array}{l}\text { Chen et al., 2003; Kang et al., 2004; } \\
\text { Lopez-Coviella et al., } 2006\end{array}$ \\
\hline BMP-11 & GDF-11 & $\begin{array}{l}\text { Axial skeleton patterning/eye } \\
\text { development/pancreas } \\
\text { development/kidney formation }\end{array}$ & $\begin{array}{l}\text { Esquela and Lee, 2003; Harmon } \\
\text { et al., 2004; Kim et al., 2005; } \\
\text { Andersson et al., } 2006\end{array}$ \\
\hline \multicolumn{4}{|c|}{ Cartilage-derived morphogenetic proteins } \\
\hline BMP-12 & CDMP-3, GDF-7 & $\begin{array}{l}\text { Ligament and tendon } \\
\text { development/development of } \\
\text { sensory neurons }\end{array}$ & Reddi, 2003; Lo et al., 2005 \\
\hline BMP-13 & CDMP-2, GDF-6 & $\begin{array}{l}\text { Cartilage development and } \\
\text { hypertrophy }\end{array}$ & Reddi, 2003 \\
\hline BMP-14 & CDMP-1, GDF-5 & Chondrogenesis/angiogenesis & $\begin{array}{l}\text { Yamashita et al., 1997; Reddi, 2003; } \\
\text { Zeng et al., } 2007\end{array}$ \\
\hline \multicolumn{4}{|l|}{ Others } \\
\hline BMP-8b & OP-3 & Spertmatogenesis & Zhao et al., 1996 \\
\hline BMP-10 & - & Heart morphogenesis & Chen et al., 2004 \\
\hline BMP-15 & GDF-9b & Ovary physiology & Knight and Glister, 2006 \\
\hline BMP-16 & Nodal & Embryonic patterning & Celeste and Murray, 1999 \\
\hline BMP-17 & Lefty & Embryonic patterning & Celeste and Murray, 2000 \\
\hline BMP-18 & Lefty & Embryonic patterning & Celeste and Murray, 2000 \\
\hline
\end{tabular}

BMPs known to induce complete bone morphogenesis are underlined. 
clearly possess pivotal roles in controlling the proliferation and differentiation fates of cells. In bone formation a clear bone-inducing role is observed for BMP-2, 4, $-6,-7$ and -9 . These BMPs have been shown to induce bone mineralisation and increase in osteocalcin levels in C2C12 cells (Chen et al., 2003) and orthotopic ossification in mice (Kang et al., 2004). BMP-3 and $3 \mathrm{~b}$ are possibly inhibitors or negative regulators of osteogenesis, as these downregulate the expression of ALP in bone cells (Hino et al., 2004). During fracture healing different BMPs follow specific defined temporal sequences. BMP-2 appears to be an early factor peaking at day 1 after fracture while BMP-14 peaks at day 7 during cartilage formation and BMP-3, $-4,-7$ and -8 are expressed mainly after 2 weeks (Cho et al., 2002). In analogy different BMPs are also expressed in site-specific patterns during the formation of bone (Zoricic et al., 2003).

\subsection{Subgroups within the BMP family}

BMPs belong to TGF $\beta$ superfamily, which includes several other growth factors, such as activins, inhibins or TGF $\beta$ s. The members of the BMP family may be subdivided into different subgroups based in their gene homology and similarity in protein structure (Wozney and Rosen, 1998; Kishigami and Mishina, 2005; Reddi, 2005; see Table 2). The proteins within the BMP-2/4 group, osteogenic protein-1 (OP-1) group, BMP-9/10 group and BMP-12/13/14 group share sequence similarities of more than 50\%. BMP-11 and BMP-15 are more distant members, similar to growth differentiation factors -8 and -9 , respectively. Interestingly, the morphogens named as growth and differentiation factors (GDFs) have similarity to some BMPs and could therefore be included in the BMP family. However, these are not described in this review since their biological roles are beyond bone induction, except for GDF-3 a BMP inhibitor, and GDF-8, a negative regulator of bone and muscle mass (Levine and Brivanlou, 2006; Hamrick et al., 2007). Additionally, under the term BMP are BMP-16 to -18 . These were given disclosure in patent applications (Celeste and Murray, 1999, 2000). BMP-16 is a human homologue to murine Nodal and BMP-17/18 are related to Lefty. Both have important roles during embryonic patterning, mainly by antagonising the effect of BMP signalling in mesoderm formation (Nodal) or for the establishment of left-right embryonic asymmetry (Lefty) (Meno et al., 1997; Thisse et al., 2000). Since BMP-16 to -18 are more distantly related to BMPs than to other $\mathrm{TGF} \beta$ superfamily members these should conceivably form a different group in the TGF $\beta$ superfamily, distinct from BMPs.

\section{The structure of BMPs}

BMPs as all members of the TGF $\beta$ superfamily, are homo or heterodimers linked via disulphide bridges. These
Table 2. Suggested subgroups within BMP family (grouped by similarity to $\mathrm{OP}-1$ )

\begin{tabular}{ll}
\hline Subgroup & Members of TGF $\beta$ superfamily \\
\hline OP-1 (BMP-7) & BMP-5, $-6,-7,-8,-8 b$ \\
BMP-2/4 & BMP-2, -4 \\
CDMP1/2/3 & BMP-12, -13,-14 (GDF-5, 6, 7) \\
BMP-9/10 & BMP-9 (GDF-2), BMP-10 \\
BMP-3/3b & BMP-3, BMP-3b (GDF-10) \\
BMP-11/GDF-8 & BMP-11 (GDF-11), GDF-8 \\
BMP-15/GDF-9 & BMP-15 (GDF-9b), GDF-9 \\
\hline
\end{tabular}

proteins are expressed as large precursor polypeptide chains containing a hydrophobic signal sequence, a long and poorly conserved $\mathrm{N}$-terminal pro-region sequence, a mature domain with a highly conserved C-terminal region and an $\mathrm{N}$-terminal region that varies among the different BMPs.

BMPs are biologically active in homodimer and heterodimer conformation (Israel et al., 1996). BMPs form a conserved motif of seven cysteines, which is involved in the formation of six intrachain disulphide bonds and a single interchain bond, necessary to dimer formation. Heterodimers in cell cultures have been observed to induce much higher yields of osteogenic marker alkaline phosphatase (ALP) (Aono et al., 1995) than homodimeric BMP. Moreover, BMP-4/7 heterodimers have also been reported for their very potent mesoderm inducing activity in Xenopus (Suzuki et al., 1997). A role has been attributed to heterodimers of BMP-4/8b in primordial germ cell formation (Ying et al., 2001). In humans, there is evidence that BMP heterodimers may be also involved in specific biological processes (Butler and Dodd, 2003), challenging researchers to look for working with heterodimers besides the widely documented investigation with BMP homodimers.

Intracellularly BMPs are produced as precursors that dissociate after proteolytical cleavage by subtilisin-like proprotein convertases to form mature proteins (Ge et al., 2005). However, in some cases the pro-region remains associated after secretion to the extracellular space, inhibiting the binding of BMPs to cell receptors. Importantly, propeptide forms of mature BMPs have been linked to specific physiological roles, such as in synovial rheumatoid arthritis for proBMP-2 and proBMP-6 (Lories et al., 2007), and in the stabilisation of BMPs in the cases of proBMP-4 (Degnin et al., 2004) and proBMP-9 (Brown et al., 2005). It is possible that the half-life of mature BMPs may be influenced by the identity of their prosequences, and that prodomains serve for other cellular effects (Gregory et al., 2005) which by itself is an important consideration for tissue-engineering approaches involving the use of these morphogens.

\subsection{Wrist and knuckle epitopes}

During the last years crystallographic studies have provided insights into the structure of BMPs and their interaction with receptors upon binding. Crystallographic 
studies have been reported for BMP-7 (Griffith et al., 1996), BMP-2 (Scheufler et al., 1999) BMP-9 (Scheufler et al., 1999), BMP-9 (Brown et al., 2005) and BMP-14 (Schreuder et al., 2005). These studies have revealed a common polypeptide core for BMPs and TGF $\beta$. The differences in hydrophobic core amongst these BMPs explain the different affinities for the various cell receptors and possibly for its different physiological roles (Allendorph et al., 2006). In BMP-2 two symmetrical pairs of juxtaposed epitopes were described: the wrist epitope, with affinity to BMP receptor I (BmprI), containing residues from both monomers; and the knuckle epitope, which includes residues from only one monomer, with low affinity for BMP receptor II (BmprII; Nickel et al., 2001). Mutations in epitope II lead to loss of activation of both BMP/Smad pathway and induction of ALP, or even complete inhibition of its function (Kirsch et al., 2000). Variants with antagonistic properties are exclusively generated by mutations in the knuckle epitope of BMP-2. A synthetic knuckle peptide alone was also sufficient to induce ALP, osteocalcin and ectopic bone formation in a rat model (Saito et al., 2003). Alterations in epitope I lead only to a reduction of ALP activity while activation of the BMP-Smad pathway is maintained (Knaus and Sebald, 2001). From these findings it was possible to conclude that the activation of the BMP-Smad pathway and the induction of early osteogenic marker ALP were triggered by distinct BMP-receptor complexes. Different pathways are probably triggered in consequence to the interaction between the different epitopes of BMPs and cell receptors (Hassel et al., 2003).

\section{2. $\mathrm{N}$-terminal of BMP}

Another particular feature of the structure of BMP-2 is a heparin-binding domain in the $\mathrm{N}$-terminal region of the mature polypeptide, which modifies its biological activity (Ruppert et al., 1996). Ruppert and colleagues demonstrated that the presence of the N-terminus of BMP-2 reduced its specific activity by interacting with heparinic sites in the extracellular matrix. A variant of recombinant BMP-2 was produced without this domain (EHBMP-2), and biological activity increased five-fold in a limb bud assay when compared to normal BMP-2 and was not affected by the presence of heparin. However, other studies have demonstrated that the presence of heparin binding site increased region increased retention times at the site of injury, and that this was necessary for higher osteoinductive effects (Wurzler et al., 2004). In a recent work a basic core of only three amino acids in the N-terminal region of BMP-4 was demonstrated to be required for its site restriction to the non-neural ectoderm (Ohkawara et al., 2002). The authors suggested that heparan sulphate proteoglycans bind to this basic core and thus play a role in trapping BMP-4. This study was the first to identify a critical domain responsible for the interaction between the BMP and the extracellular environment that restricts its diffusion in vivo. Interestingly, heparan sulphates were also observed to be required for BMP-7 signalling (Irie et al., 2003) and recently these have been observed to greatly influence the chondrogenic activity of BMPs (Fisher et al., 2006) and the transcription of several osteogenic genes in response to BMP (Manton et al., 2007). For these reasons heparin has been included in several different tissue engineering constructs using BMPs (Jeon et al., 2007; Lin et al., 2008).

\subsection{BMP antagonists}

There are diverse BMP-binding proteins that act as modulators of BMP activity or as antagonists, such as Noggin (Zimmerman et al., 1996), Chordin (Blader et al., 1997), Follistatin (Fainsod et al., 1997) and Gremlin (Hsu et al., 1998). These are extracellular regulator proteins that prevent the BMP assembly to cell receptors and in this way modulate the effect of BMP signalling during the formation of tissues. Crystallographic studies showed that the binding of antagonists, such as Noggin, to BMPs inhibited its signalling through blocking the binding of BMP epitopes for type I and type II receptors to which BMPs bind (Groppe et al., 2002). Recently, two new cofactors that regulate BMP signalling, Betaglycan and crypto, were described (Dale et al., 2004). Betaglycan formed a complex with inhibins which binds to activin type II receptors, thus preventing BMP signalling (Wiater and Vale, 2003). Because of the association of these proteins with various diseases and with additional biological roles, the generation of antagonists of $\operatorname{TGF} \beta$ superfamily members might generate potent tools for basic research and therapeutic approaches (Gazzerro and Canalis, 2006).

\section{BMP signalling - from cell receptor to gene activation}

BMPs, and all members of the TGF $\beta$ superfamily, bind to serine-threonine kinase receptors on the cell surface, triggering specific intracellular pathways that activate and influence gene transcription, having precise effects in cell proliferation and differentiation (Figure 1). There are types I, II and III receptors for TGF $\beta$ superfamily members. Only types I and II appear to play significant roles in BMP binding and signalling, both of which are required for signal transduction (Heldin et al., 1997; Shi and Massague, 2003). For the BMP family, significantly more ligands than receptors are known. To the best of our knowledge the main receptors to which most BMPs bind are type I receptors activin receptor Ia (ActR-I or Alk2), Bmprla (Alk3) and BmprIb (Alk6) and the type II receptors BMP receptor II (BmprII), activin type II receptor (ActR-II) and activin type IIB receptor (ActR-IIB) (Derynck and Zhang, 2003). However, type III TGF- $\beta$ receptors have been shown to serve as cell receptors for BMP signalling, mediating epithelial to mesenchymal cell conversion (Kirkbride et al. 2008). 


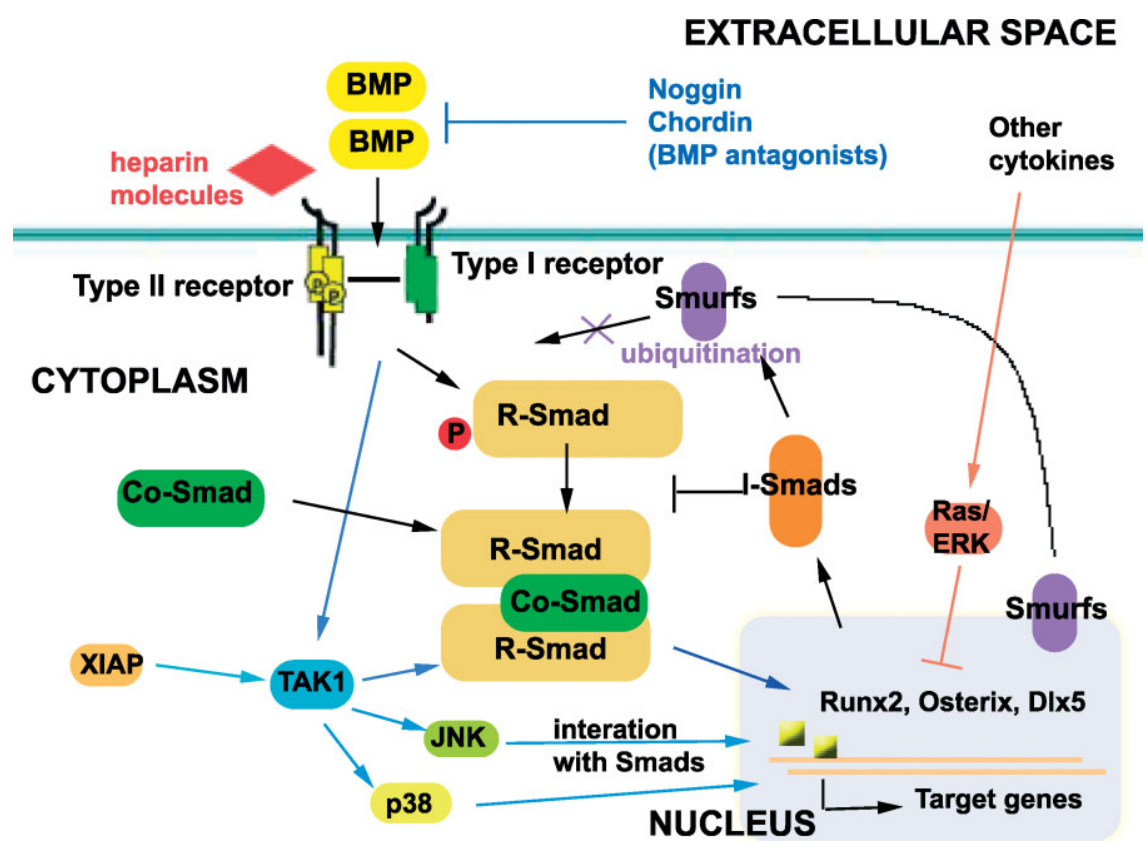

Figure 1. BMP signalling pathways: schematic representation of Smad-dependent and -independent pathways and their main mechanisms of modulation

Upon BMP binding low-affinity type II receptors are constitutively activated and type I receptors are activated by the transphosphorylation of the glycine-serine (GS)rich domain of these receptors (Heldin et al., 1997). Therefore, the specificity of intracellular signals is mainly determined by type I receptors (Miyazono et al., 2005). BMP2-binding to preformed receptor complexes induces the SMAD pathway whereas signalling complexes sequentially assembled by BMP2 result in the activation of p38-mitogen-activated protein kinase (MAPK; Hassel et al., 2003). Different combinations of type I and type II receptors are the key to providing different and specific signals which result in different cell effects (Sebald et al., 2004). In fact, a recent study showed that Alk3 (type Ia) and Alk6 (type Ib) BMP receptors may transmit different signals during the specification and differentiation of mesenchymal lineages (Kaps et al., 2004). BMP-2 and BMP-4 bind preferentially to Alk3 and Alk6, whereas the BMP-7 group binds more to Alk2 and Alk6. BMP-14 (GDF5) binds to Alk6, but not efficiently to other receptors (Miyazono and Miyazawa, 2002), and the same is noted for BMP-15 (Shimasaki et al., 2004; Tsumaki and Yoshikawa, 2005). BMP-13 (GDF6) binds to Alk3 (Kishigami and Mishina, 2005). All these BMPs activate Smad-1, -5 and -8 signalling, whereas for TGF $\beta$, Nodal and activins, Smad-2 and -3 are mainly involved (Shimasaki et al., 2004; Tsumaki and Yoshikawa, 2005). Differently, BMP-11 binds to Alk4, -5 and -7 to activate Smad-3 signalling (Andersson et al., 2006). It has been shown that BMP-3 binds to Alk4 type I receptor and that it may block BMP signalling by competing with ActR-IIB and reducing Smad-1, -5, -8 or Smad-2, -3 phosphorylation (Gamer et al., 2005). Finally, activin receptor-like kinase 1 (Alk1) was identified as a potential receptor for BMP9 (Brown et al., 2005) acting through Smad-1 and -5 signalling (Lopez-Coviella et al., 2006). Mutations in the BMP receptors have been described to cause diseases. Mutations in the BmprII gene have been found in patients with primary pulmonary hypertension (PPH; Lane et al., 2000); those in the BmprIA gene have been found in some patients with juvenile polyposis (Howe et al., 2001). Furthermore, proteomic studies have revealed that the Cterminal tail of BMP receptors type II is also involved in the regulation of cytoskeletal proteins (Hassel et al., 2004). Targeting BMP cell receptors may then be an alternative way to mediate bone-inducing stimuli in tissue-engineering approaches.

\subsection{BMP/Smad signalling}

Smads are the main signal transducers of serine-threonine receptors (Derynck and Zhang, 2003). Upon BMP binding, type I receptors phosphorylate receptor-regulated Smads (R-Smads). Different R-Smads were identified in mammals: Smad1, Smad5, Smad8 and possibly Smad9 (Xu et al., 2003). Activated RSmads form a complex with common-partner Smad (Co-Smad) (Xu et al., 2003). There is only one described Co-Smad, Smad4. Two phosphorylated R-Smads form a heterotrimeric complex with one Co-Smad, which is translocated into the nucleus and modulates gene transcription with cooperation with other transcription factors (Massague and Wotton, 2000; Derynck and Zhang, 2003; Vincent et al., 2003). All R-Smads are activated by BMP-2 or -4 , whereas BMP- $6,-7$ and -9 only efficiently induce Smad1 and -5 but not Smad8 (Aoki et al., 2001; Brown et al., 2005). Negative regulation of BMP-induced Smad signal transduction is modulated by inhibitory Smads (ISmads). I-Smads act by inhibiting the activation of type I 
receptors upon BMP binding (Hanyu et al., 2001). Smad6 and -7 act as I-Smads. Smad6 preferentially inhibits BMP signalling while Smad7 inhibits both TGF $\beta$-activin and BMP signalling. I-Smads also interact with R-Smads, preventing the formation of the complex with Smad4 (Murakami et al., 2003) inhibiting the transcription of specific genes (Edlund et al., 2003). BMP signalling is also modulated by ubiquitin-dependent protein degradation. Smad ubiquitin regulatory factors (Smurfs) induce the ubiquitination and degradation of Smads thus controlling the signal of BMP. Smurfs form a complex with inhibitory Smad7, which associates with type I receptors, promoting the ubiquitination and degradation of these receptors (Murakami et al., 2003). Interestingly, Smurfs also enhance the responsiveness to Smad2, which mediates TGF $\beta$ signalling and has as opposite effect to that of BMPs (Zhu et al., 1999; Zhang et al., 2001). The Smad signalling pathway has been also investigated in cancer treatment (Leivonen and Kahari, 2007; ten Dijke and Arthur, 2007; Katoh, 2007). By controlling the different Smad signalling and thus specific cell responses, researchers could in the near future not only achieve a better knowledge of how BMPs but also modulate the subtle biological roles inherent to the diverse TGF- $\beta$ and BMP members (Schmierer and Hill, 2007).

\subsection{BMP/MAPK signalling}

Mitogen-activated protein kinase (MAPK) pathways are alternative pathways that are also implicated in the signal transduction of BMPs (Derynck and Zhang, 2003; Massague, 2003). There are three characterised MAPK pathways in mammalian cells: the extracellularsignal regulated kinases (ERKs); the c-Jun-NH2-terminal kinases (JNKs); and the p38 MAPK pathways. These pathways are triggered either by cytokines such as BMPs or by environmental stress (Tibbles and Woodgett, 1999). Thus it may be of importance for biomedical purposes that MAPK pathways are considered since these are connected to a wide range of cellular responses. Cooperative interactions have been reported between Smads and transcription factors activated by MAPK pathways. The X-linked inhibitor of apoptosis links the BMP receptor signalling to TGF $\beta 1$-activated tyrosine kinase 1 (TAK1) and activates p38 and JNK kinases and nuclear factor-kappaB (NF- $\kappa$ B) (Silverman et al., 2003; Takaesu et al., 2003). In osteoprogenitor cells TAK1 interacts with Smads, thus interfering with the BMP signals and osteogenic differentiation (Hoffmann et al., 2005). MAPK pathways interact with other pathways mediated by different cytokines such as epithelial growth factor (EGF), insulin-like growth factor (IGF) or fibroblast growth factor (FGF) (Massague, 2003). These act by extracellular signal-regulated kinases which inhibit the BMP-Smad signalling through Ras/Raf/Mek (Aubin et al., 2004). It was reported that during embryonic differentiation activation of these pathways inhibit the BMP signalling thus favouring neural differentiation
(Pera et al., 2003). It appears that MAPK pathways modulate BMP-Smad signalling through interaction with two conserved globular domains present in Smads, the MH1 and MH2 domains. The MH1 domain is involved in DNA binding and the MH2 domain in binding to cytoplasmic retention factors, activated receptors, nucleoporins in the nuclear pore, and DNA-binding cofactors, coactivators and corepressors in the nucleus (Yamamoto et al., 2003). Recently, it has been shown that MAPK pathways promoted the termination of Smadmediated BMP signalling, in Xenopus (Fuentealba et al., 2007). The simultaneously application of BMPs and other cytokines in therapeutical situations may therefore have specific antagonistic or synergistic effects depending on the interactions occurring between the signalling pathways triggered by each growth factor.

\subsection{BMP gene modulation}

When translocated to the nucleus, Smads regulate gene transcription by interacting and binding to specific DNA sequences and DNA-binding proteins, such as transcriptional factors (Miyazono et al., 2000). BMPactivated Smads bind preferentially to the GCCGnCGC sequence of target genes and only weakly to AGAC or GTCT gene sequences, which are preferentially bound by TGF $\beta$ - or activin-activated Smads (Kusanagi et al., 2000). Smads also interact with transcriptional factors and transcriptional coactivators and corepressors.

Runt-related transcription Factor (Runx) is one the most studied transcription factors for BMP signalling, regulating processes such as bone formation and haematopoiesis (Ito and Miyazono, 2003). Three isoforms have been identified in mammals: Runx1, Runx2 (also known as Cbfa1, core binding factor A1) and Runx3. The three are reported to interact with R-Smads. Runx2 cooperatively regulates transcription of genes leading to the differentiation of mesenchymal progenitor cells into osteoblasts (Zhang et al., 2000; Miyazono et al., 2004), and for this reason is widely screened as a marker for commitment of cells into the osteochondral lineage and differentiation into bone. Expression levels of Runx2 are low in mesenchymal cells and are induced upon BMP signalling (Maeda et al., 2004). The induction of Runx2 is mediated by a balance between two transcription factors, Dlx5 and Msx2, that responding to BMP signalling, triggering the activation of Runx2 (Miyama et al., 1999; Lee et al., 2003, 2005). Diverse osteogenic markers are then induced by Runx2, such as ALP, osteocalcin, osteopontin and others (Kumar et al., 2005; Takahashi et al., 2005), which are closely related to the process of endochondral calcification.

Osterix (OSX) is another transcription factor that is mediated by BMP/Smad signals and probably by MAPK signalling and other pathways (Celil et al., 2005). Osterix, together with Runx2, are the most studied transcription factors specific for BMP signalling, involved in the differentiation of mesenchymal stem cells into 
bone cells (Satija et al., 2007). Smad signalling also interacts with other proteins such as ATF4, TAZ, and NFATc1 transcriptional factors (Deng et al, 2008), Hoxc8 (Shi et al., 1999), MyoD (Liu et al., 2001), OAZ (Hata et al., 2000), Msx1 (Yamamoto et al., 2000), and SIP1 (Verschueren et al., 1999). Menin is another required factor that regulates Runx2-induced transcription of genes during the early commitment phase of osteoblast differentiation (Sowa et al., 2004). Among the several BMP target genes, Id (inhibitor of differentiation or inhibitor of DNA binding) proteins are some of the most important ones (Ogata et al., 1993). Id proteins function as negative regulators of cell differentiation and as positive regulators of cell proliferation (Yokota, 2001). Recent advances in microarray analysis enable the identification of many BMP target genes in diverse cell types (Clancy et al., 2003; Garcia et al., 2002; Korchynskyi et al., 2003; Kowanetz et al., 2004) and allow a better understanding of the physiological effects of BMPs.

\subsection{Cross-talk with other pathways}

BMP signalling is modulated by cross-talk with several other pathways in a very elaborate network of interacting molecules. BMP and TGF $\beta$-activin pathways compete with each other, as they share similar signalling molecules, such as Smad-4 (Candia et al., 1997). Inhibitory Smads are also modulated by several other cytokines and the presence of shear stress in cells (Miyazono et al., 2000). Expression of endogenous TGF $\beta$ in preosteoblastic differentiation cells induces I-Smads, which regulate a faster or slower BMP-induced differentiating effect (Maeda et al., 2004). The BMP-Smad pathway was also observed to interact in either synergistic or antagonistic ways with other signalling pathways, such as the Notch pathway (Dahlqvist et al., 2003), the EGF pathway (Kretzschmar et al., 1997), the STAT/LIF pathway (Nakashima et al., 1999), the Wnt pathway (Nishita et al., 2000), IGF and FGF signalling (Pera et al., 2003) and in convergence/antagonistic effect with the MAP kinase pathway (Aubin et al., 2004). MAPK pathway has also been shown to enhance BMP signalling in response to collagen stimulus through activation of the Ras-ERK pathway (Suzawa et al., 2002). These molecular pathways have been involved in modulating BMP signalling in diverse cellular effects and processes, such as osteoblast maturation (Zamurovic et al., 2004), migration of endothelial cells (Itoh et al., 2004), epithelial-to-mesenchymal cell transition (Zavadil et al., 2004) and inhibition of myogenic differentiation (Dahlqvist et al., 2003).

\subsection{Recombinant BMPs for tissue engineering}

After Urist's pioneering experiments in 1965, BMPs were extracted and purified from bone of several different species including rabbit (Urist et al., 1979), cow (Wang et al., 1988) and human (Urist et al., 1983). Isolation of native BMP from bone results in very low yields around $1-2 \mu \mathrm{g} / \mathrm{kg}$ cortical bone. The need for obtaining larger quantities of BMPs for tissue engineering prompted researchers to produce and purify these growth factors by DNA recombinant technology (Table 3).

Nowadays, recombinant BMPs are produced mainly by two expression systems: in mammalian cells or in bacteria. With mammalian cells the recombinant protein is obtained active but yields are usually very low. With bacteria the protein is obtained in much larger yields but usually in non-soluble inactive inclusion bodies which are later solubilised and refolded to yield bioactive protein. A common disadvantage is that the protein is not glycosylated as is normal in the human body and thus may present reduced stability or biological activity.

Recombinant human BMP-2 was first obtained in mammalian cell cultures from Chinese hamster ovary (CHO) cells (Wang et al., 1990a). The rhBMP-2 induced ectopic bone and cartilage formation when implanted

Table 3. Selected works reporting the production of recombinant BMPs in diverse expression systems

\begin{tabular}{|c|c|c|c|}
\hline BMP & Expression system & Novelty & References \\
\hline BMP2 & CHO cells & $\begin{array}{l}\text { Bone formation, characterisation of } \\
\text { expressed BMP-2 }\end{array}$ & $\begin{array}{l}\text { Wang et al., 1990b; Israel et al., } \\
1992\end{array}$ \\
\hline BMP2 & Insect cells & Alternative expression system & Maruoka et al., 1995 \\
\hline BMP2 & E. coli & $\begin{array}{l}\text { The heparin binding domain reduces ALP } \\
\text { and specific in vitro biological activity }\end{array}$ & Ruppert et al., 1996 \\
\hline BMP2 & E. coli & High density expression in bacteria & Li et al., 1998 \\
\hline BMP2 & E. coli, pCYTEXP3 & $\begin{array}{l}\text { Optimisation of refolding conditions for } \\
\text { BMP-2 }\end{array}$ & $\begin{array}{l}\text { Vallejo et al., 2002; Vallejo and } \\
\text { Rinas, } 2004\end{array}$ \\
\hline BMP2 & E. coli & $\begin{array}{l}\text { Additional heparin binding domains } \\
\text { enhance in vivo bone formation }\end{array}$ & Wurzler et al., 2004. \\
\hline BMP2 & E. coli, pET-11a & Comparison with BMP-2 propeptide & Hillger et al., 2005 \\
\hline BMP2 & E. coli, pET-21a & Use of different refolding buffers & Long et al., 2006 \\
\hline BMP2 & E. coli, pET-25b & Bioactivity in human stem cells & Bessa et al., 2008 \\
\hline BMP4 & E. coli & Bone formation in mice & Kubler et al., 1998a \\
\hline BMP4 & E. coli, pET-11a & Stability in physiological buffer & Klosch et al., 2005 \\
\hline BMP6 & E. coli, pET-15b & Induction of several osteogenic markers & Yang et al., 2003 \\
\hline BMP7 & $\mathrm{CHO}$ cells & Bioactivity in rats & Sampath et al., 1992 \\
\hline BMP2/7, 4/7 & $\mathrm{CHO}$ cells & Heterodimer expression & Israel et al., 1996 \\
\hline
\end{tabular}


in rats after 2 weeks. Characterization of rhBMP-2 produced in $\mathrm{CHO}$ cells led to the conclusion that the protein was secreted in three forms, a propeptide of $40-45 \mathrm{kDa}$, a mature homodimer of $30 \mathrm{kDa}$ and a small portion of uncleaved precursor of $60 \mathrm{kDa}$ (Israel et al., 1992). The mature peptide possessed N-glycosylation. Sampath et al. confirmed the bioactivity of rhBMP-7 from $\mathrm{CHO}$ cells by analysis of bone formation and specific osteogenic markers, such as osteocalcin (Sampath et al., 1992). Koenig et al. (1994) noticed a strong tendency of recombinant BMP-2 to adhere non-specifically to culture dishes or to the negatively charged extracellular matrix via its positively charged N-terminal. They modified the BMP by a mild trypsin digestion, removing the first seven to nine residues, and named it digit-removed BMP-2, that still binds to the BMP receptor. Nowadays, commercial recombinant human BMP-2 lack this N-terminal heparinbinding end, since the region decreases the specific bioactivity of the BMP (Ruppert et al., 1996).

In 1996, various combinations of rhBMPs were coexpressed in $\mathrm{CHO}$ cells to test for possible heterodimer formation (Israel et al., 1996). Transient co-expression between the different rhBMPs resulted in more bioactivity than expression of any single rhBMP. The rhBMP- $2 / 7$ heterodimer yielded 20 -fold higher activity in the in vivo ALP assay. In 1998 Kubler and colleagues produced rhBMP-2 and -4 in Escherichia coli and rhBMPs were tested in a collagen carrier and induced bone formation in rats after 4 weeks (Kubler et al., 1998a, 1998b). Recombinant human BMP-6 was later expressed and purified in $E$. coli (Yang et al., 2003), using pET-15b vector. The protein was obtained in inclusion bodies, refolded and induced ALP activity in C3H10T1/2 cells and other osteogenic markers, as observed by RT-PCR.

During the last years, Vallejo and colleagues reported interesting works regarding the production of rhBMP2 in inclusion bodies, with optimized protein refolding procedures (Vallejo et al., 2002; Vallejo and Rinas, 2004). The group found that refolding of BMP-2 was particularly sensitive to $\mathrm{pH}$, temperature and concentration, but not so much to ionic strength or redox conditions. The rhBMP-2 was refolded in buffer with L-arginine or CHES at $\mathrm{pH} 8.5$ to a yield of $750 \mathrm{mg}$ dimer per litre of bacteria growing media.

In 2005, mature rhBMP-2, unprocessed rhBMP-2 and propeptide of rhBMP-2 were produced in E. coli (Hillger et al., 2005), using a pET-11a expression vector. This group reported bioactivity from both the propeptide and an N-terminal truncated BMP-2 form. Curiously, in 2004, Wurzler and co-workers used mutants of rhBMP-2 with enhanced heparin binding sites (in the N-terminus) and a variant with no heparin binding site. The variant with no binding site showed great reduction in osteoinduction, while the mutants with additional heparin binding sites led to enhanced bone formation, due to longer retention times of the BMP-2 in the extracellular matrix (Wurzler et al., 2004; Depprich et al., 2005). This fact could be of great interest for drug-delivery approaches providing recombinant proteins with increased affinity for binding to the extracellular matrix itself in vivo. In 2005, rat BMP-4 has been expressed and purified as inclusion bodies in Escherichia coli that are stable in a physiological compatible buffer showing bioactivity in MC3T3-E1 cells (Klosch et al., 2005).

A report on the production of rhBMP-2 was published in 2006, using pET-21a in E. coli. The protein, obtained in inclusion bodies, was refolded in different folding buffers (Long et al., 2006). RhBMP-2 was best refolded at low concentrations $(0.1 \mathrm{mg} / \mathrm{ml}), 4^{\circ} \mathrm{C}$ and in the presence of L-arginine. Recently, soluble rhBMP-2 was obtained upon production with the use of pET25b E. coli vector. The rhBMP-2 showed bioactivity in primary cultures of human fat-derived stem cells and an increase in levels of osteogenic markers Runx2, Osterix and Smad-1 and -5 in the C2C12 cell line (Bessa et al., 2008).

\subsection{From manufacture of BMPs to tissue-engineering products}

Since their discovery in 1965, BMPs have revealed a promising future in the field of tissue engineering as powerful components of biomedical products for the regeneration of body parts of human patients, namely bone and cartilage. At present, the state of the art of regenerative medicine envisages the use of growth factors, loaded into scaffolding materials and using precursor or stem cells, possibly from the patient him/herself. It is expected that future advances in fundamental biology will allow researchers to design novel tissue-engineering strategies that make use of combinations of different BMPs and other growth factors. The use of these growth factor cocktails will certainly present a challenging approach in tissue engineering since much is still poorly understood about the orchestration of molecular cascades underlying the regeneration of tissues.

Currently, there are two products approved by the Food and Drug Administration (FDA) consisting of recombinant BMP-2 and BMP-7 loaded into absorbable collagen sponges for clinical use for fusion of spinal vertebrae and treatment of long bone fractures (McKay et al., 2007; White et al., 2007). However, a whole set of other less understood BMPs will probably make its way into the clinic, such as with the case of cartilagederived morphogenetic proteins (BMP-12, -13 and -14) for cartilage or tendon reconstruction, or BMP-9 that has stronger osteogenic potencies compared to other BMPs (Kang et al. 2004). Recombinant BMPs used in clinics are derived from mammalian expression cells, which elevates much of the cost of clinical products containing rhBMPs. It is expected that advances in recombinant technology namely those involving the large-scale production of BMPs in bacteria will allow researchers to obtain and use these proteins at a much lower cost.

At present, recombinant technology is also a useful tool to achieve molecular modifications of BMPs to improve their bioactivity, stability and affinity to both the tissue-engineering scaffold or the extracellular 
Table 4. Chemical or genetic engineering modifications for improving particular characteristics of BMPs for use in tissue engineering applications

\begin{tabular}{|c|c|c|}
\hline Modification process & Advantages & References \\
\hline $\begin{array}{l}\text { Enzymatic cleavage of BMP heparin } \\
\text { binding domain }\end{array}$ & $\begin{array}{l}\text { Reduces non-specific interactions with } \\
\text { extracellular matrix, leading to increased } \\
\text { bioactivity in vitro }\end{array}$ & $\begin{array}{l}\text { Koenig et al., 1994; Uludag et al., } \\
2001\end{array}$ \\
\hline Plasmin enzymatic cleavage of BMP & $\begin{array}{l}\text { Reduces non-specific interactions with } \\
\text { extracellular matrix, leading to increased } \\
\text { bioactivity in vitro }\end{array}$ & $\begin{array}{l}\text { Israel et al., 1992; Hollinger et al., } \\
1998\end{array}$ \\
\hline $\begin{array}{l}\text { Adding additional heparin binding } \\
\text { domains }\end{array}$ & $\begin{array}{l}\text { Increases retention to extracellular matrix or } \\
\text { affinity to biomaterial, leading to increased } \\
\text { activity in vivo }\end{array}$ & $\begin{array}{l}\text { Wurzler et al., 2004; Depprich et al., } \\
2005\end{array}$ \\
\hline $\begin{array}{l}\text { Immobilisation of synthetic peptides } \\
\text { of partial BMP sequences }\end{array}$ & $\begin{array}{l}\text { Improves the stability and specific activity of } \\
\text { the BMP and reduces the initial burst release }\end{array}$ & $\begin{array}{l}\text { Suzuki et al., 2000; Saito et al., } \\
\text { 2003, 2004, 2005; Saito et al., 2006; } \\
\text { Seol et al., 2006; Bergeron et al., } \\
\text { 2007; Park et al., } 2007\end{array}$ \\
\hline $\begin{array}{l}\text { Fusion protein BMP with domain to } \\
\text { bind a specific biomaterial }\end{array}$ & $\begin{array}{l}\text { Increases the retention of BMP on carrier, } \\
\text { accelerating tissue regeneration; increases } \\
\text { stability and activity of the BMP }\end{array}$ & $\begin{array}{l}\text { Han et al., 2002; Schmoekel et al., } \\
2005\end{array}$ \\
\hline $\begin{array}{l}\text { Fusion protein BMP with RGD for } \\
\text { enhanced cell attachment or domain } \\
\text { for other specific biological function }\end{array}$ & $\begin{array}{l}\text { Enhances attachment of cells, tissue } \\
\text { regeneration and possibly the } \\
\text { biocompatibility of the material }\end{array}$ & Not yet reported \\
\hline Chemical modification of BMP, such & Enhances the affinity for binding to the & Hollinger et al., 1998; Uludag et al., \\
\hline $\begin{array}{l}\text { as with succinylation, acetylation or } \\
\text { biotinylation, changes the isoelectric } \\
\text { point }\end{array}$ & $\begin{array}{l}\text { biomaterial by changing the peptide } \\
\text { solubility, to suit a desired release profile }\end{array}$ & $\begin{array}{l}\text { 1999a; Uludag et al., 1999b; Uludag } \\
\text { et al., 2000; Uludag et al., } 2001\end{array}$ \\
\hline $\begin{array}{l}\text { Formation of heterodimers between } \\
\text { different BMPs }\end{array}$ & $\begin{array}{l}\text { The increased bioactivity of BMP } \\
\text { heterodimers leads to lower dose }\end{array}$ & $\begin{array}{l}\text { Zhu et al., } 2006 \text { Aono et al., 1995; } \\
\text { Israel et al., } 1996\end{array}$ \\
\hline
\end{tabular}

matrix and cells (see Table 4). For example, by adding additional heparin binding domains, there is a significantly different bioactivity and bioavailability of the rhBMP, decreasing its specific activity in vitro but increasing bone formation in vivo (Depprich et al., 2005). Currently, most recombinant BMP-2 and BMP-7 are produced with no heparin binding domain and thus may present reduced bioactivity when used for clinical uses. Another approach may consist of producing recombinant peptides containing only the binding sites to the cell receptors thus achieving specific biological effects with no problems derived from loss of bioactivity or stability which occur during the incorporation into the scaffold (Suzuki et al., 2000; Saito et al., 2003, 2004, 2005, 2006). Designing chimeric proteins is a further powerful approach which may include the addition of other domains of biological importance such as immune modulatory agents, RGD for increased cell attachment, GFP for in vivo localization, or domains for specific binding to biomaterials such as for example to collagen (Han et al., 2002) or to fibrin (Schmoekel et al., 2005). Naturally, the chimeric rhBMPs would have different refolding characteristics as compared to native proteins. These could have altered stability, solubility, surface binding and bioactivity/biospecificity thus making an appealing approach of producing specifictissue target proteins and with increased bioactivity (Oppermann et al., 2005). Chemical modification also improves binding, stability, bioactivity and bioavailability of BMPs (Luginbuehl et al., 2004). Thus, by chemically or recombinantly modifying the isoelectric point of the BMP the affinity of the BMPs to the delivery matrices could be greatly enhanced that allows the achievement of a desired release profile. Chemically modified rhBMP-2 with enhanced affinity to carriers has been reported by succinylation (Hollinger et al., 1998), acetylation (Uludag et al., 2000) and biotinylation (Uludag et al., 1999b). Finally, the expression of recombinant BMP heterodimers is another way of obtaining these growth factors with much increased bioactivity (Aono et al., 1995; Israel et al., 1996).

Despite being promising recombinant technology is still at as early stage, since there is a need to bypass some fundamental limitations, such as optimising the stability and bioactivity of recombinant BMPs, obtaining glycosylation patterns identical to that of native BMP, and reducing the possibility of triggering immunogenic responses when used in clinical situations. In the next years, the combination of advances of the BMP field with that of biomaterial science (Mano et al., 2007) will surely herald a revealing future for the use of these morphogens for biomedical and tissue-engineering applications.

\section{Acknowledgements}

The author wishes to thank Johan Benesch and Isabel João for critical reviewing of the manuscript. This work was supported by Fundação para a Ciência e Tecnologia (PhD Grant No. SFRH/BD/17049/2004) and carried out under the scope of the European NoE EXPERTISSUES (NMP3-CT-2004-500283). This study was performed according to ethical guidelines. No conflicts of interest are stated.

\section{References}

Andersson O, Reissmann E, Ibanez CF. 2006; Growth differentiation factor 11 signals through the transforming growth factor-beta 
receptor ALK5 to regionalize the anterior-posterior axis. EMBO Rep 7: 831-837.

Aoki H, Fujii M, Imamura T, et al. 2001; Synergistic effects of different bone morphogenetic protein type I receptors on alkaline phosphatase induction. $J$ Cell Sci 114: 1483-1489.

Aono A, Hazama M, Notoya K, et al. 1995; Potent ectopic bone-inducing activity of bone morphogenetic protein-4/7 heterodimer. Biochem Biophys Res Commun 210: 670-677.

Aubin J, Davy A, Soriano P. 2004; In vivo convergence of BMP and MAPK signaling pathways: impact of differential Smad1 phosphorylation on development and homeostasis. Genes Dev 18: 1482-1494.

Bergeron E, Marquis ME, Chretien I, et al. 2007; Differentiation of preosteoblasts using a delivery system with BMPs and bioactive glass microspheres. J Mater Sci Mater Med 18: 255-263.

Bessa PC, Pedro AJ, Klosch B, et al. 2008; Osteoinduction in human fat-derived stem cells by recombinant human bone morphogenetic protein-2 produced in Escherichia coli, Biotechnol Lett, 30: 15-21.

Blader P, Rastegar S, Fischer N, et al. 1997; Cleavage of the BMP-4 antagonist chordin by zebrafish tolloid. Science 278: 1937-1940.

Brown MA, Zhao Q, Baker KA, et al. 2005; Crystal structure of BMP9 and functional interactions with pro-region and receptors. $J$ Biol Chem 280: 25111-25118.

Butler SJ, Dodd J. 2003; A role for BMP heterodimers in roof platemediated repulsion of commissural axons. Neuron 38: 389-401.

Callis TE, Cao D, Wang DZ. 2005; Bone morphogenetic protein signaling modulates myocardin transactivation of cardiac genes. Circ Res 97: 992-1000.

Candia AF, Watabe T, Hawley SH, et al. 1997; Cellular interpretation of multiple TGF $\beta$ signals: intracellular antagonism between activin/BVg1 and BMP-2/4 signaling mediated by Smads. Development 124: 4467-4480.

Celeste AJ, Murray BL. 1999; Nucleic acids encoding bone morphogenic protein-16 (BMP-16). US Patent No. 596503.

Celeste AJ, Murray BL. 2000; Bone morphogenetic protein (BMP)-17 and BMP-18 compositions. US Patent No. 6027917.

Celil AB， Hollinger JO，Campbell PG. 2005; Osx transcriptional regulation is mediated by additional pathways to BMP2/Smad signaling. $J$ Cell Biochem 95: 518-528.

Chen C, Grzegorzewski KJ, Barash S, et al. 2003; An integrated functional genomics screening program reveals a role for BMP-9 in glucose homeostasis. Nat Biotechnol 21: 294-301.

Chen H, Shi S, Acosta L, et al. 2004; BMP10 is essential for maintaining cardiac growth during murine cardiogenesis. Development 131: 2219-2231.

Cho TJ, Gerstenfeld LC, Einhorn TA. 2002; Differential temporal expression of members of the transforming growth factor beta superfamily during murine fracture healing. J Bone Miner Res 17: 513-520.

Clancy BM, Johnson JD, Lambert AJ, et al. 2003; A gene expression profile for endochondral bone formation: oligonucleotide microarrays establish novel connections between known genes and BMP-2-induced bone formation in mouse quadriceps. Bone 33: $46-63$.

Dahlqvist C, Blokzijl A, Chapman G, et al. 2003; Functional Notch signaling is required for BMP4-induced inhibition of myogenic differentiation. Development 130: 6089-6099.

Dale RA, Harrison JS, Redding SW. 2004; Oral complications in cancer chemotherapy, cancer incidence, and mortality in the US. Gen Dent 52: 64-71; quiz, 72.

Degnin C, Jean F, Thomas G, et al. 2004; Cleavages within the prodomain direct intracellular trafficking and degradation of mature bone morphogenetic protein-4. Mol Biol Cell 15: 5012-5020.

Depprich R, Handschel J, Sebald W, et al. 2005; [Comparison of the osteogenic activity of bone morphogenetic protein (BMP) mutants]. Mund Kiefer Gesichtschir 9: 363-368 [in German].

Derynck R, Zhang YE. 2003; Smad-dependent and Smadindependent pathways in TGF $\beta$ family signalling. Nature 425: 577-584.

Edlund S, Bu S, Schuster N, et al. 2003; Transforming growth factorbeta1 (TGF $\beta$ )-induced apoptosis of prostate cancer cells involves Smad7-dependent activation of p38 by TGF $\beta$-activated kinase 1 and mitogen-activated protein kinase kinase 3. Mol Biol Cell 14: 529-544.

Esquela AF, Lee SJ. 2003; Regulation of metanephric kidney development by growth/differentiation factor 11. Dev Biol 257: $356-370$.
Fainsod A, Deissler K, Yelin R, et al. 1997; The dorsalizing and neural inducing gene follistatin is an antagonist of BMP-4. Mech Dev 63: $39-50$

Fisher MC, Li Y, Seghatoleslami MR, et al. 2006; Heparan sulfate proteoglycans including syndecan-3 modulate BMP activity during limb cartilage differentiation. Matrix Biol 25: 27-39.

Gamer LW, Nove J, Levin M, et al. 2005; BMP-3 is a novel inhibitor of both activin and BMP-4 signaling in Xenopus embryos. Dev Biol 285: $156-168$

Ge G, Hopkins DR, Ho WB, et al. 2005; GDF11 forms a bone morphogenetic protein 1-activated latent complex that can modulate nerve growth factor-induced differentiation of PC12 cells. Mol Cell Biol 25: 5846-5858.

Gitelman SE, Kobrin MS, Ye JQ, et al. 1994; Recombinant Vgr1/BMP-6-expressing tumors induce fibrosis and endochondral bone formation in vivo. J Cell Biol 126: 1595-1609.

Gregory KE, Ono RN, Charbonneau NL, et al. 2005; The prodomain of BMP-7 targets the BMP-7 complex to the extracellular matrix. $J$ Biol Chem 280: 27970-27980.

Griffith DL, Keck PC, Sampath TK, et al. 1996; Three-dimensional structure of recombinant human osteogenic protein 1: structural paradigm for the transforming growth factor beta superfamily. Proc Natl Acad Sci USA 93: 878-883.

Groppe J, Greenwald J, Wiater E, et al. 2002; Structural basis of BMP signalling inhibition by the cystine knot protein Noggin. Nature 420: $636-642$

Hamrick MW, Shi X, Zhang W, et al. 2007; Loss of myostatin (GDF8) function increases osteogenic differentiation of bone marrowderived mesenchymal stem cells but the osteogenic effect is ablated with unloading. Bone 40: 1544-1553.

Han B, Perelman N, Tang B, et al. 2002; Collagen-targeted BMP3 fusion proteins arrayed on collagen matrices or porous ceramics impregnated with type I collagen enhance osteogenesis in a rat cranial defect model. J Orthop Res 20: 747-755.

Hanyu A, Ishidou Y, Ebisawa T, et al. 2001; The N domain of Smad7 is essential for specific inhibition of transforming growth factorbeta signaling. J Cell Biol 155: 1017-1027.

Harmon EB, Apelqvist AA, Smart NG, et al. 2004; GDF11 modulates NGN3 $^{+}$islet progenitor cell number and promotes $\beta$ cell differentiation in pancreas development. Development 131: 6163-6174.

Hassel S, Eichner A, Yakymovych M, et al. 2004; Proteins associated with type II bone morphogenetic protein receptor (BMPR-II) and identified by two-dimensional gel electrophoresis and mass spectrometry. Proteomics 4: 1346-1358.

Hassel S, Schmitt S, Hartung A, et al. 2003; Initiation of Smaddependent and Smad-independent signaling via distinct BMPreceptor complexes. J Bone Joint Surg Am 85A(suppl 3): 44-51.

Hata A, Seoane J, Lagna G, et al. 2000; OAZ uses distinct DNAand protein-binding zinc fingers in separate BMP-Smad and Olf signaling pathways. Cell 100: 229-240.

Heldin CH, Miyazono K, ten Dijke P. 1997; TGF $\beta$ signalling from cell membrane to nucleus through SMAD proteins. Nature 390: 465-471.

Hillger F, Herr G, Rudolph R, et al. 2005; Biophysical comparison of BMP-2, ProBMP-2, and the free pro-peptide reveals stabilization of the pro-peptide by the mature growth factor. J Biol Chem 280: 14974-14980.

Hino J, Kangawa K, Matsuo H, et al. 2004; Bone morphogenetic protein-3 family members and their biological functions. Front Biosci 9: 1520-1529.

Hoffmann A, Preobrazhenska O, Wodarczyk C, et al. 2005; Transforming growth factor-beta-activated kinase-1 (TAK1), a MAP3K, interacts with Smad proteins and interferes with osteogenesis in murine mesenchymal progenitors. $J$ Biol Chem 280: 27271-27283.

Hollinger JO, Uludag H, Winn SR. 1998; Sustained release emphasizing recombinant human bone morphogenetic protein-2. Adv Drug Deliv Rev 31: 303-318.

Howe JR, Bair JL, Sayed MG, et al. 2001; Germline mutations of the gene encoding bone morphogenetic protein receptor $1 \mathrm{~A}$ in juvenile polyposis. Nat Genet 28: 184-187.

Hsu DR, Economides AN, Wang X, et al. 1998; The Xenopus dorsalizing factor Gremlin identifies a novel family of secreted proteins that antagonize BMP activities. Mol Cell 1: 673-683.

Irie A, Habuchi H, Kimata K, et al. 2003; Heparan sulfate is required for bone morphogenetic protein-7 signaling. Biochem Biophys Res Commun 308: 858-865. 
Israel DI, Nove J, Kerns KM, et al. 1996; Heterodimeric bone morphogenetic proteins show enhanced activity in vitro and in vivo. Growth Factors 13: 291-300.

Israel DI, Nove J, Kerns KM, et al. 1992; Expression and characterization of bone morphogenetic protein-2 in Chinese hamster ovary cells. Growth Factors 7: 139-150.

Ito Y, Miyazono K. 2003; RUNX transcription factors as key targets of TGF $\beta$ superfamily signaling. Curr Opin Genet Dev 13: 43-47.

Itoh F, Itoh S, Goumans MJ, et al. 2004; Synergy and antagonism between Notch and BMP receptor signaling pathways in endothelial cells. EMBO $J$ 23: 541-551.

Kang Q, Sun MH, Cheng H, et al. 2004; Characterization of the distinct orthotopic bone-forming activity of 14 BMPs using recombinant adenovirus-mediated gene delivery. Gene Ther 11: $1312-1320$.

Kaps C, Hoffmann A, Zilberman Y, et al. 2004; Distinct roles of BMP receptors type IA and IB in osteo-/chondrogenic differentiation in mesenchymal progenitors (C3H10T1/2). Biofactors 20: 71-84.

Kessler E, Takahara K, Biniaminov L, et al. 1996; Bone morphogenetic protein-1: the type I procollagen C-proteinase. Science 271: 360-362.

Kim J, Wu HH, Lander AD, et al. 2005; GDF11 controls the timing of progenitor cell competence in developing retina. Science 308: 1927-1930.

Kirsch T, Nickel J, Sebald W. 2000; BMP-2 antagonists emerge from alterations in the low-affinity binding epitope for receptor BMPR-II. EMBO J 19: 3314-3324.

Kishigami S, Mishina Y. 2005; BMP signaling and early embryonic patterning. Cytokine Growth Factor Rev 16: 265-278.

Klosch B, Furst W, Kneidinger R, et al. 2005; Expression and purification of biologically active rat bone morphogenetic protein4 produced as inclusion bodies in recombinant Escherichia coli. Biotechnol Lett 27: 1559-1564.

Knaus P, Sebald W. 2001; Cooperativity of binding epitopes and receptor chains in the BMP/TGF $\beta$ superfamily. Biol Chem 382: 1189-1195

Knight PG, Glister C. 2006; TGF $\beta$ superfamily members and ovarian follicle development. Reproduction 132: 191-206.

Koenig BB, Cook JS, Wolsing DH, et al. 1994; Characterization and cloning of a receptor for BMP-2 and BMP-4 from NIH 3T3 cells. Mol Cell Biol 14: 5961-5974.

Korchynskyi O, Dechering KJ, Sijbers AM, et al. 2003; Gene array analysis of bone morphogenetic protein type I receptor-induced osteoblast differentiation. J Bone Miner Res 18: 1177-1185.

Kowanetz M, Valcourt U, Bergstrom R, et al. 2004; Id2 and Id3 define the potency of cell proliferation and differentiation responses to transforming growth factor beta and bone morphogenetic protein. Mol Cell Biol 24: 4241-4254.

Kretzschmar M, Doody J, Massague J. 1997; Opposing BMP and EGF signalling pathways converge on the TGF $\beta$ family mediator Smad1. Nature 389: 618-622.

Kubler NR, Moser M, Berr K, et al. 1998a; [Biological activity of E. coli expressed BMP-4]. Mund Kiefer Gesichtschir 2(suppl 1): S149-152.

Kubler NR, Reuther JF, Faller G, et al. 1998b; Inductive properties of recombinant human BMP-2 produced in a bacterial expression system. Int J Oral Maxillofac Surg 27: 305-309.

Kumar S, Mahendra G, Ponnazhagan S. 2005; Determination of osteoprogenitor-specific promoter activity in mouse mesenchymal stem cells by recombinant adeno-associated virus transduction. Biochim Biophys Acta 1731: 95-103.

Kusanagi K, Inoue H, Ishidou Y, et al. 2000; Characterization of a bone morphogenetic protein-responsive Smad-binding element. Mol Biol Cell 11: 555-565.

Lane KB, Machado RD, Pauciulo MW, et al. 2000; Heterozygous germline mutations in BMPR2, encoding a TGF $\beta$ receptor, cause familial primary pulmonary hypertension. The International $\mathrm{PPH}$ Consortium. Nat Genet 26: 81-84.

Lee $\mathrm{MH}$, Kim YJ, Kim HJ, et al. 2003; BMP-2-induced Runx2 expression is mediated by Dlx5, and TGF $\beta 1$ opposes the BMP2-induced osteoblast differentiation by suppression of Dlx5 expression. $J$ Biol Chem 278: 34387-34394.

Lee $\mathrm{MH}$, Kim YJ, Yoon WJ, et al. 2005; Dlx5 specifically regulates Runx2 type II expression by binding to homeodomain-response elements in the Runx2 distal promoter. $J$ Biol Chem 280: 35579-35587.

Levander G. 1934; On the formation of new bone in bone transplantation. Acta Chir Scand 74: 425-426.
Levander G. 1938; A study of bone regeneration. Surg Gynecol Obstet 67: $705-714$.

Levine AJ, Brivanlou AH. 2006; GDF3, a BMP inhibitor, regulates cell fate in stem cells and early embryos. Development 133: 209-216.

Li M, Chen C, Pu Q, et al. 1998; Production of human recombinant bone morphogenetic protein-2A by high density culture of Escherichia coli with stationary dissolved oxygen fed-batch condition. Chin J Biotechnol 14: 157-163.

Liu D, Black BL, Derynck R. 2001; TGF $\beta$ inhibits muscle differentiation through functional repression of myogenic transcription factors by Smad3. Genes Dev 15: 2950-2966.

Lo L, Dormand EL, Anderson DJ. 2005; Late-emigrating neural crest cells in the roof plate are restricted to a sensory fate by GDF7. Proc Natl Acad Sci USA 102: 7192-7197.

Long L, MacLean MR, Jeffery TK, et al. 2006; Serotonin increases susceptibility to pulmonary hypertension in BMPR2-deficient mice. Circ Res 98: 818-827.

Lopez-Coviella I, Mellott TM, Kovacheva VP, et al. 2006; Developmental pattern of expression of BMP receptors and Smads and activation of Smad1 and Smad5 by BMP9 in mouse basal forebrain. Brain Res 1088: 49-56.

Lories RJ, Derese I, de Bari C, et al. 2007; Evidence for uncoupling of inflammation and joint remodeling in a mouse model of spondylarthritis. Arthrit Rheum 56: 489-497.

Luginbuehl V, Meinel L, Merkle HP, et al. 2004; Localized delivery of growth factors for bone repair. Eur $J$ Pharm Biopharm 58: 197-208.

Luyten FP, Chen P, Paralkar V, et al. 1994; Recombinant bone morphogenetic protein-4, transforming growth factor-beta 1 , and activin A enhance the cartilage phenotype of articular chondrocytes in vitro. Exp Cell Res 210: 224-229.

Maeda S, Hayashi M, Komiya S, et al. 2004; Endogenous TGF $\beta$ signaling suppresses maturation of osteoblastic mesenchymal cells. EMBO J 23: 552-563.

Mano JF, Silva GA, Azevedo HS, et al. 2007; Natural origin biodegradable systems in tissue engineering and regenerative medicine: present status and some moving trends. $J R$ Soc Interface 4: 999-1030.

Maruoka Y, Oida S, Iimura T, et al. 1995; Production of functional human bone morphogenetic protein-2 using a Baculovirus system. J Dent Res 74: 568-568.

Massague J. 2003; Integration of Smad and MAPK pathways: a link and a linker revisited. Genes Dev 17: 2993-2997.

Massague J, Wotton D. 2000; Transcriptional control by the TGF $\beta$ /Smad signaling system. EMBO J 19: 1745-1754.

Meno C, Ito Y, Saijoh Y, et al. 1997; Two closely-related left-right asymmetrically expressed genes, lefty-1 and lefty-2: their distinct expression domains, chromosomal linkage and direct neuralizing activity in Xenopus embryos. Genes Cells 2: 513-524.

Miyama K, Yamada G, Yamamoto TS, et al. 1999; A BMP-inducible gene, $d l x 5$, regulates osteoblast differentiation and mesoderm induction. Dev Biol 208: 123-133.

Miyazono K, Maeda S, Imamura T. 2004; Coordinate regulation of cell growth and differentiation by TGF $\beta$ superfamily and Runx proteins. Oncogene 23: 4232-4237.

Miyazono K, Maeda S, Imamura T. 2005; BMP receptor signaling: transcriptional targets, regulation of signals, and signaling crosstalk. Cytokine Growth Factor Rev 16: 251-263.

Miyazono K and Miyazawa K. 2002; Id: a target of BMP signaling. Science signaling, 2002: PE40.

Miyazono K, ten Dijke P, Heldin CH. 2000; TGF $\beta$ signaling by Smad proteins. Adv Immunol 75: 115-157.

Murakami G, Watabe T, Takaoka K, et al. 2003; Cooperative inhibition of bone morphogenetic protein signaling by Smurf1 and inhibitory Smads. Mol Biol Cell 14: 2809-2817.

Nakashima K, Yanagisawa M, Arakawa H, et al. 1999; Synergistic signaling in fetal brain by STAT3-Smad1 complex bridged by p300. Science 284: 479-482.

Nakashima M, Reddi AH. 2003; The application of bone morphogenetic proteins to dental tissue engineering. Nat Biotechnol 21: 1025-1032.

Nickel J, Dreyer MK, Kirsch T, et al. 2001; The crystal structure of the BMP-2:BMPR-IA complex and the generation of BMP-2 antagonists. J Bone Joint Surg Am 83A(suppl 1): S7-14.

Nishita M, Hashimoto MK, Ogata S, et al. 2000; Interaction between Wnt and TGF $\beta$ signalling pathways during formation of Spemann's organizer. Nature 403: 781-785.

Ogata T, Wozney JM, Benezra R, et al. 1993; Bone morphogenetic protein-2 transiently enhances expression of a gene, Id (inhibitor 
of differentiation), encoding a helix-loop-helix molecule in osteoblast-like cells. Proc Natl Acad Sci USA 90: 9219-9222.

Ohkawara B, Iemura S, ten Dijke P, et al. 2002; Action range of BMP is defined by its N-terminal basic amino acid core. Curr Biol 12: 205-209.

Oppermann H, Tai M, McCartney J. 2005; Modified proteins of the TGF $\beta$ superfamily, including morphogenic proteins/US Patent No. 6846906.

Oxburgh L, Dudley AT, Godin RE, et al. 2005; BMP4 substitutes for loss of BMP7 during kidney development. Dev Biol 286: 637-646.

Ozkaynak E, Schnegelsberg PN, Jin DF, et al. 1992; Osteogenic protein-2. A new member of the transforming growth factorbeta superfamily expressed early in embryogenesis. $J$ Biol Chem 267: 25220-25227.

Park JB, Lee JY, Park HN, et al. 2007; Osteopromotion with synthetic oligopeptide-coated bovine bone mineral in vivo. J Periodontol 78: 157-163.

Pera EM, Ikeda A, Eivers E, et al. 2003; Integration of IGF, FGF, and anti-BMP signals via Smad1 phosphorylation in neural induction. Genes Dev 17: 3023-3028.

Qi X, Li TG, Hao J, et al. 2004; BMP4 supports self-renewal of embryonic stem cells by inhibiting mitogen-activated protein kinase pathways. Proc Natl Acad Sci USA 101: 6027-6032.

Reddi AH. 1981; Cell biology and biochemistry of endochondral bone development. Coll Relat Res 1: 209-226.

Reddi AH. 1998; Cartilage-derived morphogenetic proteins and cartilage morphogenesis. Microsc Res Technol 43: 131-136.

Reddi AH. 2003; Cartilage morphogenetic proteins: role in joint development, homoeostasis, and regeneration. Ann Rheum Dis 62(suppl 2): ii73-78.

Reddi AH. 2005; BMPs: from bone morphogenetic proteins to body morphogenetic proteins. Cytokine Growth Factor Rev 16: 249-250.

Reddi AH, Huggins C. 1972; Biochemical sequences in the transformation of normal fibroblasts in adolescent rats. Proc Natl Acad Sci USA 69: 1601-1605.

Rickard DJ, Hofbauer LC, Bonde SK, et al. 1998; Bone morphogenetic protein- 6 production in human osteoblastic cell lines. Selective regulation by oestrogen. $J$ Clin Invest 101: 413-422.

Ruppert R, Hoffmann E, Sebald W. 1996; Human bone morphogenetic protein 2 contains a heparin-binding site which modifies its biological activity. Eur J Biochem 237: 295-302.

Saito A, Suzuki Y, Kitamura M, et al. 2006; Repair of $20 \mathrm{~mm}$ long rabbit radial bone defects using BMP-derived peptide combined with an $\alpha$-tricalcium phosphate scaffold. J Biomed Mater Res A 77: 700-706.

Saito A, Suzuki Y, Ogata S, et al. 2003; Activation of osteoprogenitor cells by a novel synthetic peptide derived from the bone morphogenetic protein-2 knuckle epitope. Biochim Biophys Acta 1651: 60-67.

Saito A, Suzuki Y, Ogata S, et al. 2004; Prolonged ectopic calcification induced by BMP-2-derived synthetic peptide. $J$ Biomed Mater Res A 70: 115-121.

Saito A, Suzuki Y, Ogata S, et al. 2005; Accelerated bone repair with the use of a synthetic BMP-2-derived peptide and bone-marrow stromal cells. J Biomed Mater Res A 72: 77-82.

Sampath TK, Maliakal JC, Hauschka PV, et al. 1992; Recombinant human osteogenic protein-1 (hOP-1) induces new bone formation in vivo with a specific activity comparable with natural bovine osteogenic protein and stimulates osteoblast proliferation and differentiation in vitro. J Biol Chem 267: 20352-20362.

Sampath TK, Reddi AH. 1981; Dissociative extraction and reconstitution of extracellular matrix components involved in local bone differentiation. Proc Natl Acad Sci USA 78: 7599-7603.

Satija NK, Gurudutta GU, Sharma S, et al. 2007; Mesenchymal stem cells: molecular targets for tissue engineering. Stem Cells Dev 16: $7-23$.

Scheufler C, Sebald W, Hulsmeyer M. 1999; Crystal structure of human bone morphogenetic protein-2 at 2.7 A resolution. $J \mathrm{Mol}$ Biol 287: 103-115.

Schmoekel HG, Weber FE, Schense JC, et al. 2005; Bone repair with a form of BMP-2 engineered for incorporation into fibrin cell ingrowth matrices. Biotechnol Bioeng 89: 253-262.

Schreuder H, Liesum A, Pohl J, et al. 2005; Crystal structure of recombinant human growth and differentiation factor 5: evidence for interaction of the type I and type II receptor-binding sites. Biochem Biophys Res Commun 329: 1076-1086.
Sebald W, Nickel J, Zhang JL, et al. 2004; Molecular recognition in bone morphogenetic protein (BMP)/receptor interaction. Biol Chem 385: 697-710.

Seeherman H, Wozney JM. 2005; Delivery of bone morphogenetic proteins for orthopedic tissue regeneration. Cytokine Growth Factor Rev 16: 329-345

Senn N. 1889; On the healing of aseptic bone cavities by implantation of antiseptic decalcified bone. Am J Med Sci 98: 219-243.

Seol YJ, Park YJ, Lee SC, et al. 2006; Enhanced osteogenic promotion around dental implants with synthetic binding motif mimicking bone morphogenetic protein (BMP)-2. J Biomed Mater Res A 77: 599-607.

Shi X, Yang X, Chen D, et al. 1999; Smad1 interacts with homeobox DNA-binding proteins in bone morphogenetic protein signaling. $J$ Biol Chem 274: 13711-13717.

Shi Y, Massague J. 2003; Mechanisms of TGF $\beta$ signaling from cell membrane to the nucleus. Cell 113: 685-700.

Shimasaki S, Moore RK, Otsuka F, et al. 2004; The bone morphogenetic protein system in mammalian reproduction. Endocr Rev 25: 72-101.

Silverman N, Zhou R, Erlich RL, et al. 2003; Immune activation of NF- $\kappa$ B and JNK requires Drosophila TAK1. J Biol Chem 278: 48928-48934.

Simic P, Vukicevic S. 2005; Bone morphogenetic proteins in development and homeostasis of kidney. Cytokine Growth Factor Rev 16: 299-308.

Sowa H, Kaji H, Hendy GN, et al. 2004; Menin is required for bone morphogenetic protein 2- and transforming growth factor betaregulated osteoblastic differentiation through interaction with Smads and Runx2. J Biol Chem 279: 40267-40275.

Suzawa M, Tamura Y, Fukumoto S, et al. 2002; Stimulation of Smad1 transcriptional activity by Ras-extracellular signalregulated kinase pathway: a possible mechanism for collagendependent osteoblastic differentiation. J Bone Miner Res 17: 240-248.

Suzuki A, Kaneko E, Maeda J, et al. 1997; Mesoderm induction by BMP-4 and -7 heterodimers. Biochem Biophys Res Commun 232: $153-156$.

Suzuki Y, Tanihara M, Suzuki K, et al. 2000; Alginate hydrogel linked with synthetic oligopeptide derived from BMP-2 allows ectopic osteoinduction in vivo. J Biomed Mater Res 50: 405-409.

Takaesu G, Surabhi RM, Park KJ, et al. 2003; TAK1 is critical for I $\kappa$ B kinase-mediated activation of the NF- $\kappa$ B pathway. $J$ Mol Biol 326: 105-115.

Takahashi T, Kato S, Suzuki N, et al. 2005; Autoregulatory mechanism of Runx2 through the expression of transcription factors and bone matrix proteins in multipotential mesenchymal cell line, ROB-C26. J Oral Sci 47: 199-207.

Thisse B, Wright CV, Thisse C. 2000; Activin- and Nodal-related factors control antero-posterior patterning of the zebrafish embryo. Nature 403: 425-428.

Tibbles LA, Woodgett JR. 1999; The stress-activated protein kinase pathways. Cell Mol Life Sci 55: 1230-1254.

Tsumaki N, Yoshikawa H. 2005; The role of bone morphogenetic proteins in endochondral bone formation. Cytokine Growth Factor Rev 16: 279-285.

Uludag H, D'Augusta D, Golden J, et al. 2000; Implantation of recombinant human bone morphogenetic proteins with biomaterial carriers: a correlation between protein pharmacokinetics and osteoinduction in the rat ectopic model. $J$ Biomed Mater Res 50: 227-238.

Uludag H, Friess W, Williams D, et al. 1999a; rhBMP-collagen sponges as osteoinductive devices: effects of in vitro sponge characteristics and protein $\mathrm{pI}$ on in vivo rhBMP pharmacokinetics. Ann N Y Acad Sci 875: 369-378.

Uludag H, Gao T, Porter TJ, et al. 2001; Delivery systems for BMPs: factors contributing to protein retention at an application site. $J$ Bone Joint Surg Am 83-A(suppl 1): S128-135.

Uludag H, Golden J, Palmer R, et al. 1999b; Biotinated bone morphogenetic protein-2: in vivo and in vitro activity. Biotechnol Bioeng 65: 668-672.

Urist MR. 1965; Bone: formation by autoinduction. Science 150: 893-899.

Urist MR, Mikulski A, Lietze A. 1979; Solubilized and insolubilized bone morphogenetic protein. Proc Natl Acad Sci USA 76: $1828-1832$.

Urist MR, Sato K, Brownell AG, et al. 1983; Human bone morphogenetic protein (hBMP). Proc Soc Exp Biol Med 173: 194-199. 
Vallejo LF, Brokelmann M, Marten S, et al. 2002; Renaturation and purification of bone morphogenetic protein-2 produced as inclusion bodies in high-cell-density cultures of recombinant Escherichia coli. J Biotechnol 94: 185-194.

Vallejo LF, Rinas U. 2004; Optimized procedure for renaturation of recombinant human bone morphogenetic protein-2 at high protein concentration. Biotechnol Bioeng 85: 601-609.

Verschueren K, Remacle JE, Collart C, et al. 1999; SIP1, a novel zinc finger/homeodomain repressor, interacts with Smad proteins and binds to $5^{\prime}$-CACCT sequences in candidate target genes. $J$ Biol Chem 274: 20489-20498.

Vincent SD, Dunn NR, Hayashi S, et al. 2003; Cell fate decisions within the mouse organizer are governed by graded Nodal signals. Genes Dev 17: 1646-1662.

Wang EA, Rosen V, Cordes P, et al. 1988; Purification and characterization of other distinct bone-inducing factors. Proc Natl Acad Sci USA 85: 9484-9488.

Wang EA, Rosen V, D’Alessandro JS, et al. 1990a; Recombinant human bone morphogenetic protein induces bone formation. Proc Natl Acad Sci USA 87: 2220-2224.

Wang EA, Rosen V, Dalessandro JS, et al. 1990b; Recombinant human bone morphogenetic protein induces bone formation. Proc Natl Acad Sci USA 87: 2220-2224.

White PM, Morrison SJ, Orimoto K, et al. 2001; Neural crest stem cells undergo cell-intrinsic developmental changes in sensitivity to instructive differentiation signals. Neuron 29: 57-71.

Wiater E, Vale W. 2003; Inhibin is an antagonist of bone morphogenetic protein signaling. J Biol Chem 278: 7934-7941.

Wozney JM and Rosen V. 1998; Bone morphogenetic protein and bone morphogenetic protein gene family in bone formation and repair, Clin Orthop Relat Res, 346: 26-37.

Wozney JM, Rosen V, Celeste AJ, et al. 1988; Novel regulators of bone formation: molecular clones and activities. Science 242: 1528-1534.

Wurzler KK, Emmert J, Eichelsbacher F, et al. 2004; [Evaluation of the osteoinductive potential of genetically modified BMP-2 variants]. Mund Kiefer Gesichtschir 8: 83-92 [in German].

$\mathrm{Xu} \mathrm{XL}$, Dai KR, Tang TT. 2003; [The role of Smads and related transcription factors in the signal transduction of bone morphogenetic protein inducing bone formation]. Zhongguo Xiu Fu Chong Jian Wai Ke Za Zhi 17: 359-362 [in Chinese].

Yamamoto M, Takahashi Y, Tabata Y. 2003; Controlled release by biodegradable hydrogyels enhances the ectopic bone formation of bone morphogenetic protein. Biomaterials 24: 4375-4383.

Yamamoto TS, Takagi C, Ueno N. 2000; Requirement of Xmsx-1 in the BMP-triggered ventralization of Xenopus embryos. Mech Dev 91: $131-141$

Yamamoto Y, Oelgeschlager M. 2004; Regulation of bone morphogenetic proteins in early embryonic development. Naturwissenschaften 91: 519-534.
Yamashita H, Shimizu A, Kato M, et al. 1997; Growth/differentiation factor-5 induces angiogenesis in vivo. Exp Cell Res 235: 218-226.

Yang JH, Zhao L, Yang S, et al. 2003; [Expression of recombinant human BMP-6 in Escherichia coli and its purification and bioassay in vitro]. Sheng Wu Gong Cheng Xue Bao 19: 556-560 [in Chinese]. Ying Y, Qi X, Zhao GQ. 2001; Induction of primordial germ cells from murine epiblasts by synergistic action of BMP4 and BMP8B signaling pathways. Proc Natl Acad Sci USA 98: 7858-7862.

Yokota Y. 2001; Id and development. Oncogene 20: 8290-8298.

Zamurovic N, Cappellen D, Rohner D, et al. 2004; Coordinated activation of notch, Wnt, and transforming growth factor-beta signaling pathways in bone morphogenic protein 2-induced osteogenesis. Notch target gene Hey1 inhibits mineralization and Runx2 transcriptional activity. J Biol Chem 279: 37704-37715.

Zavadil J, Cermak L, Soto-Nieves N, et al. 2004; Integration of $\mathrm{TGF} \beta /$ Smad and Jagged1/Notch signalling in epithelial-tomesenchymal transition. EMBO J 23: 1155-1165.

Zeng Q, Li X, Beck G, et al. 2007; Growth and differentiation factor5 (GDF-5) stimulates osteogenic differentiation and increases vascular endothelial growth factor (VEGF) levels in fat-derived stromal cells in vitro. Bone 40: 374-381.

Zhang Y, Chang C, Gehling DJ, et al. 2001; Regulation of Smad degradation and activity by Smurf2, an E3 ubiquitin ligase. Proc Natl Acad Sci USA 98: 974-979.

Zhang YW, Yasui N, Ito K, et al. 2000; A RUNX2/PEBP2 $\alpha$ A/CBFA1 mutation displaying impaired transactivation and Smad interaction in cleidocranial dysplasia. Proc Natl Acad Sci USA 97: 10549-10554.

Zhao GQ, Deng K, Labosky PA, et al. 1996; The gene encoding bone morphogenetic protein $8 \mathrm{~B}$ is required for the initiation and maintenance of spermatogenesis in the mouse. Genes Dev 10: 1657-1669.

Zhu H, Kavsak P, Abdollah S, et al. 1999; A SMAD ubiquitin ligase targets the BMP pathway and affects embryonic pattern formation. Nature 400: 687-693.

Zimmerman LB, De Jesus-Escobar JM, Harland RM. 1996; The Spemann organizer signal noggin binds and inactivates bone morphogenetic protein 4. Cell 86: 599-606.

Zoricic S, Maric I, Bobinac D, et al. 2003; Expression of bone morphogenetic proteins and cartilage-derived morphogenetic proteins during osteophyte formation in humans. $J$ Anat 202: 269-277.

Zuzarte-Luis V, Montero JA, Rodriguez-Leon J, et al. 2004; A new role for BMP5 during limb development acting through the synergic activation of Smad and MAPK pathways. Dev Biol 272: 39-52. 